\title{
The Strength of Proof of Telephone Tapping As Electronic Evidence in Revealing Corruption Cases
}

\begin{abstract}
Aga Wigana ${ }^{1}$, and Maryanto ${ }^{2}$
Abstract. This study try to answer the question: 1) Why is the wiretapping in investigations of corruption, 2) How wiretapping conducted in the investigations conducted by investigators of corruption, connected with the legal provisions in force of Indonesia 3) In the circumstances of how the interception of the telephone as electronic evidence can be accepted as evidence legitimate in the proof of corruption cases.

This research using normative juridical approach, with specification of descriptive analytical research. The data used in this research is secondary data obtained from books and scientific papers as well as data tertiary derived from articles and Internet news, dictionaries legal and material outside the legal field which is then analyzed qualitatively using equity theory, the theory of punishment, the theory of legal certainty and the theory of legal protection.

Results of the discussion concluded that Wiretapping (Interference) by phone is required to disclose the existence of corruption are the modus increasingly diverse, particularly for evidence of bribes or gratuities are not reported, the constraints are rules about wiretapping not been clearly defined, especially for police investigators and investigators prosecutors, therefore it needs to be regulated in Law on wiretapping which contains a complete 'authority, mechanism or procedure for tapping activities and results, in addition to tapping activities undertaken should continue to promote the values of human rights of citizens, in addition to telephone tapping can be accepted as valid evidence in trial of corruption cases, if the principles of retrieval and storage of electronic data (chain of custody) maintained to ensure its validity as electronic evidence in proving the case in court.

Keywords: Strength of Evidence; Tapping; Electronic Evidence; Corruption.
\end{abstract}

\section{Introduction}

The development of corruption in Indonesia in terms of quality and quantity from year to year continues to increase, the results of a recent survey released by the Corruption Perception Index (CPI) released Transparency International (IT) for the year 2018 shows that Indonesia is up seven ranks 89th out of 180 countries. Factors that encourage improved ratings CPI Indonesia is the process of trying, licensing and investment easier in Indonesia. Research Manager of Transparency International Indonesia, Wawan Sudjatmiko says: ${ }^{3}$ Indonesian CPI score in 2018 rose one point to 38 on a scale of 0-100 after being flat in the score 37 since 2016. Indonesia's ranking climbed to $89^{\text {th }}$ out of 180 countries compared to 2017 is ranked 96 of 180 countries.

\footnotetext{
${ }^{1}$ Student of Master of Law, Universitas Islam Sultan Agung Semarang and Civil Servant, email: agawigana@yahoo.com

${ }^{2}$ Lecturer of Master of Law, Sultan Agung Islamic University (UNISSULA), Semarang

3 Dimas Jarot Bayu, "Indeks Persepsi Korupsi Indonesia 2018 Naik Tujuh peringkat", published in https: //katadata.co.id/berita/2019/01/29.
} 
Indonesia's position is up seven ranks from 2017, however, Indonesia's score is still below the average score of the countries in the world for 43 . IT noted more than $60 \%$ or 120 out of 180 countries score his GPA is below 50 , factors that boost Indonesia's score significantly from Global data Insight Country Risk Ratings which is up 12 points from 35 to 47 . The increase was due to the process of trying, licensing, and investment easier in Indonesia, meanwhile, is a factor that stagnant Political Risk Services with a value of 50 . This is because there are still potential risks of corruption in the political system has not changed, except that there are indications of a suspicious relationship between politicians and businessmen. The factors that inhibit value IPK Indonesia, the IMD World Competitiveness Yearbook value is down three points from 41 to 38 , these factors explain that bribery and corruption are still present in the Indonesian political system".

The authority of law enforcement officers to carry out wiretaps in the context of law enforcement in particular in the form of a new Law are directed to the Commission. In the provisions of Article 12 paragraph (1) in conjunction with Article 12 B of Act No. 19 of 2019 regarding the Second Amendment to Act No. 30 of 2002 on the Corruption Eradication Commission, has been set on the authority of the Commission to conduct wiretaps that "in carrying out the task of examining and investigation referred to in article 6 letter e (inquiry, investigation and prosecution of corruption), the KPK is authorized to conduct wiretapping, then in article 12B paragraph (1) determined that tapping as stipulated in article 12 paragraph (1) shall be after obtaining written permission from the Board of Trustees.

Thus setting the tapping imposed for Investigator police, prosecutors or other authorized wiretapping the enforcement of corruption in terms of the procedural law until now has not been regulated specifically because of the absence of law that specifically regulates Wiretapping. Seeing these circumstances, the regulation of interception does not look similar or generalized to the entire investigation of corruption and there is no clarity regarding the mechanism or procedure for interception and wiretapping authority boundaries in detail.

In addition, the Law on Information and Electronic Transactions also give legality to the law enforcement officers to carry out or ask for the wiretapping. The explanation of Article 31, it is explained that the tapping is allowed under the Act is wiretapping conducted in the framework of law and at the request of law enforcement officers. This has different consequences with what is stipulated in the Telecommunications Act, because under articles 42 and 43 of the Telecommunications Act only gives the legality of the procedure of recording information to the request of a telecommunications provider and not give legitimacy to conduct wiretaps to law enforcement officials. ${ }^{4}$

Based on the background of the above problems, the problem is formulated as follows: Why is the wiretapping in investigations of corruption; How wiretapping conducted in the investigations conducted by investigators of corruption, connected

\footnotetext{
${ }^{4}$ Rezky Mahayu Sekarsari, Legalitas Alat bukti Elektronik hasil Penyadapan dalam Rencana Penjebakan Sebagai Upaya Penegakan Hukum, Jurist -Diction Vol. 1 No.2, November 2018contained in the file: // C: / Users / user / Downloads / accessed on 27,112,019
} 
with the legal provisions in force in Indonesia; and In the circumstances of how the results of telephone tapping as electronic evidence can be accepted as valid evidence in proving the corruption case.

\section{Research methods}

This research using normative juridical approach, with specification of descriptive analytical research. The data used in this research is secondary data obtained from books and scientific papers as well as data tertiary derived from articles and Internet news, dictionaries legal and material outside the legal field which is then analyzed qualitatively using equity theory, the theory of punishment, the theory of legal certainty and the theory of legal protection.

\section{Results and Discussion}

\subsection{Tapping Necessary For In The Corruption Crime Investigation}

According to Robert Klitgaard ${ }^{5}$ that explores corruption from the perspective of the State Administration, defines corruption of behavior that deviates from the official duties of an office of State for profit, status or money regarding personal (individual, close relatives, the group itself) or violate the operational rules concerning behavior personal.

Based on an understanding and a new dimension of crime has a development context, according to Indriyanto Seno Adjie, the understanding of corruption is no longer associated with any state financial embezzlement. Measures Bribery and kickbacks (commission unauthorized reception) is also considered as a crime. The same assessment is also given to the despicable actions of government officials such as bureaucratic corruption or corruption that are categorized as a form of offenses beyond the reach of the law (crimes not covered by the law). ${ }^{6}$

In conjunction with tapping carried out by investigators in the disclosure of corruption cases which are necessary to prove the existence of bribes or gratuities are not reported received by a government official to do or not do something for her actions undertaken unlawfully or illegally, for example regarding the sharing of fees on a procurement project or to create a favorable policy for those who want it. One of the major corruption cases that occur are related to the procurement of electronic ID cards with a budget of around Rp. 6 billion to the program Population Identification Number (VIN) to be implemented nationally in 2011 and 2012 with PNRI as the preferred bidder consortium consisting of company Perum PNRI, PT. LEN Industri, PT. Quadra Solution, PT. Sucofindo and PT. Sandipala Artha Putra involving various stakeholders from the executive branch and the legislature, but in practice there are deviations from the tender auction ID card electronically until its implementation, after an investigation by the Commission of Corruption Eradication

\footnotetext{
${ }^{5}$ Wasingatu Zakiah "Penegakan Hukum Undang-Undang Korupsi" Paper, Jakarta, p. 23.

${ }^{6}$ Dr. Chaerul Amir, SH, MH, Kejaksaan Memberantas Korupsi, Suatu Analisis Historis, Sosiologis dan Yuridis, Pro deleader, Jakarta, 2014, p. 93.
} 
(KPK) found the fact of giving and receiving bribes and the fee on the project among others by Sugiharto, Irman, Andi Narogong, Novanto and Markus Nari and the others, until the Commission found any losses that occur in the implementation of the project is Rp. 2, 314 trillion. According to the Anti-Corruption Commissioner at the time of Alexander Marwata, "e-ID card project, the country based on a count BPK losses of Rp 2.3 trillion. I'm not sure until the half of it could we return (to the state)", Sandipala Artha Putra involving various stakeholders from the executive branch and the legislature, but in practice there are deviations from the tender auction ID card electronically until its implementation, after an investigation by the Commission of Corruption Eradication (KPK) found the fact of giving and receiving bribes and the fee on the project among others by Sugiharto, Irman, Andi Narogong, Novanto and Markus Nari and the others, until the Commission found any losses that occur in the implementation of the project is Rp. 2, 314 trillion. According to the Anti-Corruption Commissioner at the time of Alexander Marwata, "e-ID card project, the country based on a count BPK losses of Rp 2.3 trillion. I'm not sure until the half of it could we return (to the state) " Sandipala Artha Putra involving various stakeholders from the executive branch and the legislature, but in practice there are deviations from the tender auction ID card electronically until its implementation, after an investigation by the Commission of Corruption Eradication (KPK) found the fact of giving and receiving bribes and the fee on the project among others by Sugiharto, Irman, Andi Narogong, Novanto and Markus Nari and the others, until the Commission found any losses that occur in the implementation of the project is Rp. 2, 314 trillion. According to the Anti-Corruption Commissioner at the time of Alexander Marwata, "e-ID card project, the country based on a count BPK losses of Rp 2.3 trillion. I'm not sure until the half of it could we return (to the state) "7

Based on the above results, according to the author, is analyzed by the theory of justice is one of the purposes of disclosure or investigation of criminal acts of corruption is to restore the state law or restore the rights of citizens who are drawn. Tapping into the street to pave the way to uncover corruption that are secretly or covertly and involve multiple parties or systemic. Often the act of corruption involving government officials or State officials, law enforcement officials and private parties whose goal produced a policy or decision of the parties favorable bribe giver and relating to projects using state budget funds are large,

For the required tapping (Interference) over the phone is to uncover the corruption that occurred are still needed given the mode of corruption are varied, mainly to prove the existence of the act of bribery or gratuities are not reported and request a fee in activities related to the position because it covert nature, but should law enforcement officials in the proof of corruption does not make evidence of wiretapping as the main evidence in exposing corruption.

\subsection{Wiretapping Activities Conducted By Investigator Of Corruption Investigation, Connected With The Legal Provisions Applicable In Indonesia}

\footnotetext{
${ }^{7}$ Negara Rugi Rp 2,3 Triliun di Proyek E-KTP, KPK Yakin Hanya Kembali Setengahnya, Kompas.com, 2017, accessed at 09.03.2020.
} 
For phone signal in Indonesia can be categorized into two, namely fixed network and mobile network. The fixed network can be used by phone using a cable, usually for home and office telephone and mobile networks include satellite, cellular phones, and radio trunking. This network is a network that is used in all countries to the process of communication with other means of communication between the phone and the mobile network may include satellite, cellular phones, and radio trunking. This network is a network that is used in all countries to the process of communication with communication devices such as phones. In Indonesia, the phone frequently used are: ${ }^{8}$ Home phone or office phone; and Mobile phone or a hand phone .

With the presence of irregularity legal provisions are scattered in various laws that cover institutions, mechanisms or procedures and the interception, the necessary realignment of the legal provisions clearly and completely related to the interception of Indonesian law in the form of an Act to establish the provision of raw and complete for all law enforcement officials are authorized to conduct wiretapping.

Establishment of the Law on Wiretapping, according to the author in it should be strictly and clearly set authority, mechanism or procedure for tapping activities along the tapper results, so that wiretapping activities conducted not become loopholes to weaken the proof of corruption itself.

Wiretap as electronic evidence conducted by the Corruption Eradication Commission has specified in article 12 of Act No. 19 of 2019 concerning Second Amendment Act No. 30 of 2002 on the Commission for the Eradication of Corruption, however, for law enforcement officers in the case this for police investigators and prosecutors, regarding the technical mechanisms tapping the legislation has not been clearly defined, therefore it needs to be regulated in the Law on wiretapping which contains a complete 'authority, mechanism or procedure for tapping activities and results that, so that wiretapping activities conducted not become loopholes to weaken the proof of corruption itself and electronic evidence obtained be valid evidence to reveal and prove the crime of corruption

\subsection{The Terms Of The Form Of The Wiretap Evidence As Electronic Evidence Can Be Accepted As Valid Evidence In The Proof Of Corruption}

Tapping in practice can not be denied is very useful as a way in the disclosure of the crime. Tapping is an accurate alternative to the criminal investigation against the development mode of crimes including the development of the results of a very serious crime. In this case, wiretapping can be viewed as a means of prevention and detection of crime. In Indonesia has been quite a lot of cases the perpetrators of serious crimes to be brought to justice thanks to the interception. ${ }^{9}$ But the other side of wiretapping without procedures and conducted by law enforcement agencies or official institutions of the country continues to be controversial because it is

\footnotetext{
${ }^{8}$ Proses Komunikasi pada jaringan telepon Http //: www.pakarkomunikasi.com, accessed on 18032020

${ }^{9}$ Erasmus Abraham Todo Napitupulu, "Melihat Pengaturan Tindak Pidana penyadapan dalam R KUHP" was published, accessed on 08122019
} 
considered as an invasion of the rights of its citizens privacy which includes the principle of privacy of personal life, family life and correspondence. Tapping as a deterrent and detection of crime also has a tendency that is harmful to human rights and vulnerable abused, when positioned on a law that was not right (because of weak regulation), and the wrong hands (because there is no control) and moreover, if the rule of law underlying not in accordance with the principles of Human rights. ${ }^{10}$

Terms tapping acceptable in the proof of corruption ie when the wiretapping carried out by law enforcement authorities in order such as law enforcement Constitutional Court Decision number: 20 / PPU-XIV / 2016, with the applicant Drs. Novanto, the verdict Constitutional Court granted the request of the applicant for most of the provisions in Article 5, paragraph (1) and (2) and Article 44 letter b UU ITE and article 26 A Act No. 20 of 2001 on the Corruption contrary to Law 1945 and does not have binding legal force throughout the camp does not mean in particular the phrase "electronic information and / or electronic documents as evidence in the context of law enforcement carried out at the request of the police,

Based on the result according to the authors, the position of the interception of the telephone as electronic evidence in a corruption case, namely, the interception of the telephone as the electronic evidence has the strength of evidence as evidence hints a rapprochement state with other evidence that witness testimony, expert testimonies and letters, another requirement is the result of telephone tapping should be obtained legally and meet the principles of Chain of custody that is documentation evidence since it was discovered until the copying and storage of evidence to maintain the originality of electronic evidence, so that the evidence in the trial, the judge would not hesitate in assessing the evidence the electronics.

Phone tapping can be accepted as valid evidence in the trial of corruption cases, if the principles of retrieval and storage of electronic data has been done correctly by the investigator, so that in the proof of the case later, there are issues that question the validity of electronic evidence or rule out electronic evidence that filed in the trial, as well as prosecutors and judges also have to understand the principles of the validity of electronic evidence, so that the evidence in the trial process that is based on electronic evidence can be conducted objectively.

\section{Closing}

\subsection{Conclusion}

- For the required tapping (Interference) over the phone is to uncover the corruption that occurred are still needed given the mode of corruption are varied, mainly to prove the existence of the act of bribery or gratuities are not reported and request a fee in activities related to the position because it covert nature, but should law enforcement officials in the proof of corruption does not make evidence of wiretapping as the main evidence in exposing corruption.

\footnotetext{
${ }^{10} \mathrm{lbid}$
} 
- Wiretap as electronic evidence conducted by the Corruption Eradication Commission has specified in article 12 of Act No. 19 of 2019 concerning Second Amendment Act No. 30 of 2002 on the Commission for the Eradication of Corruption, however, for law enforcement officers in the case this for police investigators and prosecutors, regarding the technical mechanisms tapping the legislation has not been clearly defined, therefore it needs to be regulated in the Law on wiretapping which contains a complete 'authority, mechanism or procedure for tapping activities and results that, so that wiretapping activities conducted not become loopholes to weaken the proof of corruption itself and electronic evidence obtained be valid evidence to reveal and prove the crime of corruption.

- Phone tapping can be accepted as valid evidence in the trial of corruption cases, if the principles of retrieval and storage of electronic data has been done correctly by the investigator, so that in the proof of the case later, there are issues that question the validity of electronic evidence or rule out electronic evidence that filed in the trial, as well as prosecutors and judges also have to understand the principles of the validity of electronic evidence, so that the evidence in the trial process that is based on electronic evidence can be conducted objectively.

\subsection{Suggestion}

- In order for the Act tapping is being formed, in which a clear determination of the competent institution to conduct wiretaps, mechanism or tapping techniques and materials the interception, besides tapping activities also scope expanded ie not only in the level of inquiries and investigations, but also in things look for and detect the presence of fugitive corruption and assets or the proceeds of corruption were acquired.

- As a form of protection of human rights of citizens, should wiretap in corruption cases do uphold the values of the right of private citizens, in this case there must be previous evidence strong and clear to do wiretapping to someone, then in terms of phone tapping carried out did not contain evidence of the beginning of their corruption and so can not be used as evidence, the results of telephone tapping should be destroyed.

- Government to facilitate more education and technical training, especially regarding electronic evidence collection techniques for investigating corruption to enhance the capacity of law enforcement officers who deal with corruption cases.

\section{References}

[1] Chaerul Amir., Kejaksaan Memberantas Korupsi, Suatu Analisis Historis, Sosiologis dan Yuridis, Pro deleader, Jakarta, in 2014

[2] Jarot Dimas Bayu "Indeks Persepsi Korupsi Indonesia 2018 Naik Tujuh peringkat", published in https: //katadata.co.id/berita/2019/01/29.

[3] Erasmus Abraham Todo Napitupulu, "Melihat Pengaturan Tindak Pidana penyadapan dalam R KUHP" was published, accessed on 08122019 
[4] Negara Rugi Rp 2,3 Triliun di Proyek E-KTP, KPK Yakin Hanya Kembali Setengahnya, 2017, accessed at 09.03202 million.

[5] Proses Komunikasi pada jaringan telepon Http //: www.pakarkomunikasi.com, accessed on 18032020

[6] Rezky Mahayu Sekarsari, Legalitas Alat bukti Elektronik hasil Penyadapan dalam Rencana Penjebakan Sebagai Upaya Penegakan Hukum, Jurist-Diction Vol. 1 No.2, November 2018 contained in the file: // C: / Users / user / Downloads / accessed on $27,112,019$

[7] Wasingatu zakiah "Penegakan Hukum Undang-Undang Korupsi" Paper, Jakarta. 